\title{
The Relationship between Islamic Economics And Western Economics*
}

\section{Prof. Dr. Kamal Tawfiq Hattab}

Dept. of Fiqh

College of Sharia \& Islamic Studies Kuwait University

\section{Dr. Metwally Abdel Mo'men al-Morsi}

Dept. of Administrative Science Riyadh Community College King Saud University, KSA

\section{Abstract:}

This study aims to explain the relationship between the western economic views and the Islamic economics, and the main effects of both these economic concepts.

It is worth pointing out that the western world had gained a lot of benefits from Muslim scientists, especially in the field of economics, but without giving up some main Islamic principles and restraints.

The study summed up that there is a prior need to take into concern the Islamic Economic System on height, for which the Muslim economist has to focus more and more to fact out Islamic economic visions in resolving some core economic problems, and attaining social impartiality, proficiency and prosperity.

\section{Introduction:}

At this juncture of the twenty first century convoyed with many economic difficulties, such as Inflation, depression, recession, pollution, food problem, energy, poverty, diseases, international financial crises.. etc, the proposed solutions by economists are not competent enough to solve all the glitches.

On the other hand, economists are probing into new economic systems that could address all these problems. Some western economists are moving towards Islamic economic system as a key to solve all these problems.

There is clear evidence that many of the western economics profited a lot from the heritage of many Muslim thinkers such as Imam Al- Ghazali, Ibn-Khaldun, and Al-Sheebani etc.

The questions that arise now is that, what are the ranges of expertise the western thinkers possess in the field of economics in the current economic context and what can Islamic economics do to help solve these problems.

This study is heading for the elucidating all these questions by:

\section{1- The Effects of the Islamic Economic Studies in the Western Views:}

It is indisputable that during the fifteenth century, the Europe was at its "Dark Ages" where it was an era of depression and backwardness. However, for the Muslims, this was an era of prosperity and development during the same period. Furthermore, during the tenth and

\footnotetext{
* The Authors Extend Their Appreciation to the Deanship of Scientific Research at King Saud University For Funding the Work Through the Research Group Project No. RGP-VPP-076
} 
the eleventh centuries when the Muslims were advanced in all fields, the Islamic Economies in the world were experiencing high levels of income and better living standards.

It is from that era, the following Islamic publications were published

\section{1-1- Ibn-Khaldun's Introduction (Shukeer, 1977; Awadi, 1986):}

Introduction of Ibn Khaldun Classified in Europe in the eighteenth century AD under the title "Philosophy of History" and was considered the first research in what was known then, "sociology," and some believe that the introduction of Ibn Khaldun is similar to Adam Smith's "Wealth of Nations" with the exception of the different time and the environment which separating the two books about five hundred years. (yusri, 1978)

Ibn-Khaldun's observations and ideas were unbiased and neutral in the field of economic science and his ideas and observations in economics can be analyzed as follows (Ibn Khaldoon, 1984):

a- He was the first to determine economic problems away from the religion and ethical factors.

b- Pointed out the law of demand and supply, and the factors affecting it.

c- Analyzed and generated the value of property surplus and income.

d- Adopted the dynamic way to solve economic problems by analyzing the effects of the time.

e- He saw that it was not necessary that the state determined economic activities.

\section{1-2- Al-Dalaji: -}

As the title of his book - "Poverty and the Poor People" he placed more emphasis on the poor and the unfortunate (Al-Maflok). His book was published in the fifteenth century and was a worthy attempt in economics and social science. The focal points of his book are:

a- Discusses about the core components of a successful business or a project such as availability of large capital, wider variety of goods, predictability of the state of the market, stability of the economy and so on.

b- Main factors influencing the destruction of the agricultural sector of the economy such as the weather conditions, difficulty to save for the future as they deteriorate and also the he spoke about the failure of the government to improve the agricultural sector and the corruption of the officials.

c- Factors making industries vulnerable, such as insufficient capital and labour.

d- Mental and psychological causes of poverty and whose concepts and misconceptions. According to Al-Dalaji, dependency, believing in astrology and asceticism are other causes of poverty. Asceticism is a lifestyle characterized by abstinence from various sorts of worldly pleasures often with the aim of pursuing religious and spiritual goals. He explains the importance of money in hand not in heart. Asceticism is not an inability. It also shows the status of real money as a way to live, not an end in itself.

It is evident from the above facts that Al-Dalaji has explored the main causes disturbing all the production sectors in his age, and his analysis were noble and advanced because he was the first to delve into analytical studies at his time as it has started actually in nineteenth century.

Historically, the Islamic sciences had moved to Europe through Andalusia and Sicily and after the Crusades, the Muslim Scholars made a significant impact on the development of 
economic systems of Europe by transmission of ideas and writings to Europe, especially the introduction to Ibn Khaldun, Filakh and Muflokon and in addition the book "The acquisition of livelihood preferences" of Sheibani considered by economists in the West as Encyclopedia of Economic Thought and commercial transactions (Khader, 1985).

According to Resch, "The Crusades have allowed the Europeans the opportunity to learn the superior culture held by the Muslims in Spain and Sicily, and the Muslims provided them a worthy culture, science in the field of Natural sciences, medical sciences and philosophy.

It is a well known fact that the governor of Sicily, "Frederick II" was a fan of the Islamic civilization, has played a key role in the dissemination of Arab culture into Europe (Zaqzook, 1994).

\section{2- Confessions by Western Intellectuals in Favor of Islamic Civilization}

In this era of abreast, searching for an upright antidote to help solve economic problems, Islamic Economic system is the plugged out form agreed by many intellectuals. This provides evidence that the western scholars recognized the civilization of Muslims in all fields such as politics, economics, and social policies, educational and ethical views.

\section{2-1- Jack Ostrey: (Babilly, 1995)}

In his book entitled "The economic development in Islam", highlighted on the importance of Islamic economic system and its impact in resolving numerous economic problems. His main remark in his book is that, "Muslims don't accept secular economic system, but their strong economic system is taken from the holy Quran which became an ethical economics and this will make the economic system more and more fair."

It is clear and unambiguous from the above statement by the French theorist Jack Ostrey that the atmosphere of Islamic economic is treasurable and based on ethical principles which helps in solving most economics issues faced by the society. So when the behavior of the main players in the economy such as the firms, producers and consumers committed to fairness, the balancing of the economy becomes the main driver. As a result problems of inflation and depression disappeared. On the other hand, when the supply and demand drilled by the Islamic values and ethics, then many vicious merchandises or goods die out and now worthy goods and services come into the market. Meanwhile the prices are stabilized and market uncertainty is removed.

\section{2-2- Claude Cahen: (Kahen, 1983)}

In his book titled "Arab history and Moslem people" Cahen pointed out how Islam and economic progress go parallel to each other In his own words "The whole world is made for the benefit of human being and it is a gift from god to the Prophet Mohammed operated in the field of business and encouraged it; but later laid off for his religious work".

Cahen also insisted that people should make good use of all the resources with good concern on this earth. This outlines that the allocation of resources in Islamic way is vital for economic development.

Muslims also progressed in the field of teaching and literature. Meanwhile they pioneered in the manufacturing of perfumes, leather, soaps and many other products.

\section{2-3- Herbert John Chalk: (Shama, 1980)}

According to Chalk in his book titled "Islam is a dynamic universal or international power", whilst the European rulers considered business as a bad idea, the Muslim countries 
dominated business trade cycle. Islam at that time sited no limitation between the states (Muslim states) in the look for transformation of businesses. During the Eleventh century, international trade links were improved between the Islamic states. Also due to the improvements in the communication systems, trade between countries improved and the economic growth rates were also high.

The above paragraph provides evidence Islamic Kingdoms helped in developing trade and industry during the time Europe was falling into insolvency.

The economic policy of Europe in the 17th century which was known as mercantilism was right at the time but not in the 18th century. Adam smith debunked mercantilism and promoted a laissez-faire policy and explained why Britain and other European countries spearheaded in industries.

Economics is a process and one should not take an event and worship it without knowing its shortcomings.

\section{2-4- Speech of Prince Charles:}

On the occasion of his visit to the Oxford Center for Islamic Studies, October 1993.

"As we see Islam as an enemy of the West, we ignore the greatness of the close connection between Islam and our history; many of the features that modern Europe is proud of us came from Andalusia, that Islam is part of our past and our present" (Zaqzook,1994)

\section{3- The Relationship between Western Economic Theory and Islamic Economics:}

In general, the relationship between the western economics and Islamic economics can be classified as follows:

\section{3-1- Effects of Western Economics on Islamic Economic:}

The emergence and progress of economics has several implications for Islamic economics and these can be summarized as follows

a- Methods of credit, banking systems and services used by western economics helped the emergence of Islamic Banking and Islamic Investment Banking, however, based on Islamic jurisprudence.

b- Use of statistical and mathematical methods in data collection and analysis, in order to facilitate the description of the various economic phenomena, and judging from the Islamic point of view

c- Take advantage of all branches of the economy, and the status of progress and theoretical analysis, such as a description of economic resources and how to operate and use them efficiently in order to increase production and increase the level of economic development and the rate of welfare, as well as how to manage money and credit and foreign trade, and the conduct of international payments... etc..

d- Making use of the economic theories such as the equilibrium of the consumer, producer, industry and market, concepts of economic maturity, and how to get to the fair price, and how to make a profit ... etc..

e- Reforming Islamic economic theories and rules in terms of consumption, production, savings, and investments.

f- Reforming the features of the Islamic economic system and to find remedy to overcome the economic problems of today. 


\section{3-2- The Link between Islamic Economics and the Economic Science:}

Economics consists of positive economic theory and analytical tools, and economic systems of capitalism and socialism, and mixed in addition to policies emanating from such systems and theory. Economics science has many branches, as a science of public finance, money, banking, and economic resources and economic development and international economics, economic planning in addition to analysis of micro-and macro-economy and so on.

Islamic economics is very positive about the above concepts. The Islamic Economics takes all the advantages and benefits of public interest from the above mentioned branches while rejecting all bad effects of these branches or which is against the Islamic views. Islamic economics and human economics can be compared using the following example.

According to Islamic economics while aiming to achieve maximum satisfaction in a legitimate manner, commitment to the conditions of the community is prioritized and waste is discouraged.

However, in the case of money and banking, Islam refuses interest-based system and replaced with Islamic investment bank, which proved the superiority over interest-based methods in practice.

In the case of utilization of resources, Islam rejects resource depletion, and overutilization, which leads to dissipation and extinctions.

When measuring economic development, Islam doesn't focus on averages which hide the obscene disparity in the level of welfare. In contrast, Islamic economics takes into account priorities, such as focusing on the needs and necessities and improvements in welfare and so on.

As for the tools of economic analysis, Islamic economics consider these theories as neutral analytical tools, benefits from its components, terminology and laws. But in dealing with these tools, gives those Islamic values. For example, when considering the issue of demand and factors affecting it, we find that the demand function describes these factors as follows (Yusri, 1978).

$$
\text { Q1 = (p1, rp, cp, t,I })
$$

In this case $\mathrm{Q} 1$ = quantity demanded of the good, $\mathrm{p} 1=$ price of the good, $\mathrm{rp}=$ price of alternative goods, $\mathrm{cp}=$ price of complementary goods $\mathrm{t}=$ taste, $\mathrm{I}=$ income. When Islamic economic deals with this, it adds to $\mathrm{L}=$ Legitimacy and no damage, $\mathrm{M}=$ moderation, no prodigality or parsimony. Thus, shape and structure of production also will differ, as does the size of consumer spending and the resulting effects on the function of the total consumption and the balance of the national income.

If we take another example from money theory we will find the effect on price level according to Fisher's quantity theory of money (Shfie, 1982) .

$$
\mathbf{M} \times \mathbf{V}=\mathbf{P} \times \mathbf{T}
$$

In the above formula $\mathrm{M}$ is the quantity of money, $\mathrm{V}$ - velocity of circulation, $\mathrm{T}$ - Volume of transactions and P- price level. It is clear from the equation that the price level depends on the quantity of money, speed of trading and the volume of transactions.

Islamic economics adds to this equation that the price level will drop when you cancel the interest rate, prevent monopolies and exploitation and the rule of ethics of cooperation and compassion etc.

Thus, we note that the Islamic economy takes the abstract analytical tools and subjects them to Islamic values \& rules. 
But when considering the relationship between the Islamic economic system and capitalism and socialism (Mawdodi, 1985), principles break through from faith and principles of the society.

Capitalism is based on the philosophy of the universe, existence, life, the individual is the basis and the axis of existence, therefore, had economic freedom and absolute private property, the right to achieve the maximum profit or satisfying as possible, and the competition and the market system is the mechanism which is managed by the system, resulting in an overstatement in the satisfaction of human desires, even at the expense of the poorer of society.

The socialism is on the basis of atheism and anti-religion, values, and considered as private property is the basis of all evils, and so was the abolition of private property is the only way to implement socialism, and that socialism was a clash of human nature and instincts, and resulted in the destruction and oppression, anxiety and loss caused to the communities which experimented with socialism. Based on the above, Islamic economics looks compassionate at these economies and reforms and gives guidance. Furthermore, it calls for the managers of these systems to take lessons from what happened in the Soviet Union and many of the former Eastern European nations.

Islamic economics does not stand idle at the risks to human problems, but presents its economic system encompassing many programs waiting for the application, some of which will be presented in the fourth chapter.

\section{3-3- Effects of Islamic Economics on the Western Economics:}

Some economists believe that economics is characterized by immobility and dormancy, and it needed new concepts and tools in order to continue to play a role, and many tried to rebuild economics through the use of mathematics, statistics and mathematical models and others. However, the science of economics has grown ambiguous and complex, and this was also acknowledged by many economists.

In the past two decades economic theory has entered a new phase which is a shift towards values, and this was associated with the success of Islamic economic studies in the world, both theoretical and practical.

The system of Islamic banks had shown to the world that there is an economic system and a banking system which is different from the systems prevailing, this system is not based on interest, but is based on the values. This has directed a number of international banks to address the manner in Islamic banking, such as Citibank, and HSBC Ltd etc.

Thus, a strong trend that demands including values into economics, and this popularized Islamic Economics as a study. Nowadays we find a lot of Western universities offering master's degrees and a doctorate in Islamic economic issues from the faculties of the economy, as did the Faculty of Economics in the Arab and Islamic universities, and this indicates that Islamic economics has established itself in the academic world.

\section{4- The Role of Islamic Economy in Solving Problems Faced by Mankind:}

Islamic economy is characterized by the presence of a number of controls that govern human behavior in the economic field, leading to problems to disappear or to reduce to a lower degree as possible. There are number of remedial economic tools which can be used in emergency or special situations according to Islamic Economics. Remedies are also available 
for contemporary economic problems which had worsened the situation of the world economies in the absence of implementation of Islamic Economics. Islamic economics can contribute to solve these problems through the divine guidance and human ethics.

The role of Islamic Economics in solving the human problems can be classified under three headings:

\section{4-1- Islamic Economic Rules \& Regulations:}

a- Restrictive Economic Freedom (Assal, 1968): which means to introduce laws to restrict economic freedom of individuals with legitimacy, avoid making harmful decisions and taking into account priorities and conditions of the society. This will prevent problems such as high prices, injustice, exploitation and greed that can arise from existence of monopoly powers and absolute economic freedom.

b- Dual ownership of the means of Production: Approval of the rights of individual and collective property rights leads to balance and stability. Collective ownership of the facilities essential for achieving the public interest and which do not conflict with private interest, because the interests of both sides are complementary, so if there is a conflict public interest will be prioritized, and this prevents abusing rights beyond the own interests.

c- Moderation and the Prevention of Extravagance and Parsimony: The person who overspends and wasteful is unfair and harmful to the society. As it is said the men who glut are the cause of famine, in other words, those who overspend and feel themselves full cause poverty to others. On the other hand, parsimony prevents money from being in circulation, limits trading. But moderation leads to balancing the economy and prevents unemployment, inflation and other economic problems

d- Prevent Monopoly and Hoarding: Monopoly leads to rise in price which affects the society negatively. Hoarding leads to idling of resources which prevents the society from utilizing them. This leads to fall in output, exchange and economic growth, giving to rising economic problems.

e- Urge Solidarity (Takaful) and Prevent Discord: Solidarity or interdependence leads to co-operation between people in the society and economic progress. On the other hand, disagreement between each other leads to weakness, scattering and economic backwardness, leading to many problems and crises.

f- Urge specialization and perfection: Perfection leads to save time, labor and expenses while maintaining quality and quantity, whilst, specialization leads to perfection, which increases production, leading to lesser economic problems.

g- Prevent Interest and Ambiguity \& Deceive: Interest leads to severe problems to the society. It leads to inflation, unemployment, recession, over-exploitation of resources and in addition, spread of hatred and envy in the society leading to the society suffering from anxiety, corruption and economic backwardness.

On the other hand, deceive and ignorance, especially in business contracts lead to injustice and as a result there will be conflict, hatred and division between the people which is against what Islam expects from Muslims.

\section{4-2- Islamic Economic Tools and Corrective Economic Measures:}

Economies can sometimes face critical and unforeseen situations such as famines, floods and war leading to crises and problems. What are the treatments for such similar and special circumstances? What is the treatment for the crises and problems that can arise from the lack of compliance with the controls of Islamic economics, the treatment is given in the following points. 
A- A Co-operative Society: Muslim community is characterized as a collaborative, interdependent community. Social solidarity is manifested by the presence of an unprecedented number of tools and methods. Such as guaranteed endowment, voluntary spending, in addition to Zakat, which is the most important tool in the treatment of many economic problems. History emphasizes that people of the book, who lived in Muslim society were provided full assurance as well as the poor and the week.

B- The Role of the State (Qardawi, 1980): The state has a major role to play in treating emergency problems and crises, which can be done as follows: -

a- Confiscate any money obtained by unlawful (Haram) way such as force, fraud, bribery and abuse of power, provided it was proved by an impartial investigation.

b- Stone on the foolish to the verse, "And give not unto the foolish your property" which means is righteous in using your money, as fool uses money in an unlawful way.

c- Top employees and authorities of the state also subject to law:-the ability to question the tops of state, "where did you get this money from", by following the life of Prophet Muhammad, may peace be upon him and his righteous worker, Omar may Allah be pleased with him, who sometimes gave half of his income as Zakat.

d- Controlling fund management and deposits and guarantee rights: - The state must ensure that the deposits of the customers are maintained properly by the banks and financial institutions and they are legitimate and oblige to the agreements of the contracts, and ensure quality and prevent fraud and deceit.

e- Spending on public interest: - the state may collect some money from the rich to use it in emergency as Omar may Allah be pleased with him" did. His approach was that the rich to share their money with others, as people will not die half stomach.

\section{4-3- Role of Islamic Economics in the Treatment of Contemporary Economic Problems of the World}

We can explain this aspect by taking into account some of the contemporary economic issues, how they are treated by human economics and their effectiveness, and the alternative solutions available in Islamic Economics to solve these problems. Some of the most important problems faced by contemporary economy are the food problem, unemployment, inflation, power, loss of sources, pollution, and poverty etc. Following explain how such problems can be solved using Islamic economic concepts.

\section{4-3-1- Food Problems:}

It is understood that economists are finding solution for shortage of food, since ancient time. Perhaps the most popular solution adopted by many economists in the past and present is birth control, based on the famous theory of Malthus (Nameq, 1980).

According to Malthusian theory of population, population increases in a geometrical ratio $(2,4,8,16,32 \ldots$ etc), whereas food supply increases in an arithmetic ratio $(1,2,3,4,5 \ldots$ etc $)$.. This difference will lead to widespread poverty and starvation, which would only be balanced by natural occurrences such as disease, high infant mortality, famine, war or moral restraint. According to this theory there are two ways to control the population: preventative and positive checks. Preventative means control in birth rate, and uses of different methods to control birth; and positive checks means natural calamities, war, etc. 
Despite this theory being proven wrong, in theory and practice, some economists, social scientists and politicians still consider that birth control is the best solution for the food problem, especially in the third world economies. Although many governments in Muslim countries have adopted policies and intensive programs for birth control, the food problem is more acute in most Islamic countries.

According to Islamic economics, birth control is not an acceptable solution. But the remedy lies in the use of such an increase in population in a positive manner by using Islamic Economic principals, such as affordability, better choice, ability to choose qualified workers, and abstinence for the unable.

These controls make the Muslim population growth to a positive and effective increase in the production, development and alleviate the problem of poverty and the resulting problems of food, health, and education.

\section{4-3-2- Inflation:}

Inflation is the most complex problem faced by all modern economies. Inflation is the continuous rise in prices mainly caused by the increase in aggregate demand due to increased money in circulation over and above the increase in aggregate supply. This leads to fall in the value of currency and continuous fall in real income due to the deterioration in production.

Positive economics attempts to solve this problem using monetary and fiscal policies. When using monetary policy, interest rates are raised which increases the proportion of bonds and reserves in the open market and reduces the money in circulation. This also reduces investment activity which is one of the elements of aggregate demand and as a result there will be fall in aggregate demand which slows down inflation. On the other hand, fiscal policy attempts to raise taxes and reduce subsidies which reduces money supply and aggregate demand and reduces inflation. Though, in theory, these policies seem to be convincing, the practical reality confirms that the problem is more complicated, since we can hardly find a single state has got rid of inflation permanently, without being accompanied by the emergence of problems and crises may be more dangerous than inflation.

According to Islamic Economics, the following are some ways to overcome the problem of inflation (Mashhor, 1992).

a- Influence demand by concentrating on necessary needs and improvements and reduce consumption on luxuries, blind imitation and flaunt.

b- The state can also restrict the money supply in line with the GDP growth. Money supply must be increased only for economic reasons, not for political reasons such as printing money to finance budget deficit.

c- Also impose restrictions on credit creation process carried out by commercial banks.

d- Seek international loans only in necessary and in exceptional cases, given that there is ability to pay. If not, the ideal way is to use the money of the rich in the country.

e- Contribute in the provision of Zakat to help the needy and this way the burden on the budget can also be eased.

\section{4-3-3- Unemployment and Recession:}

High rates of inflation leading to the inability of spending by people with low income lead to fall in demand for goods and services which results in a depression. In addition to this, 
as the firms desire to decrease costs may force to reduce wages for workers and eventually laying off some workers, which will result in unemployment.

Once again to solve these problems, the human economics uses fiscal and monetary policies, but the reality proves that these problems are rooted in contemporary economies.

But countries using Islamic Economics we rarely find a recession because of applying principals that suits the conditions of the society and consistent with the legislative goals. Goods and services will not be produced unless it is to satisfy the needs of the society. Also, marketing will not be dependent on advertising, persuasion, ostentation or imitation but depending on the real needs of the community.

On the other hand, unemployment is low in such economies because the workers are part of an interdependent society, is not discharged, except in the most exceptional cases, and then the task of finding a job is with the State.

\section{4-3-4- Problem of Resource Depletion and Environmental Pollution:}

The methods and policies used in production by the capitalists, whose main motive is maximizing profits, are harmful to the society. These unjust actions include, over exploitation of resources, especially the non-renewable ones, deforestation, dumping the nuclear and other wastes to the rivers and seas polluting them, dumping excess production and disposing chemical wastes in the third world countries.

Although human rights, animal rights and environment friendly activists are trying their best to curb the greed of the selfish and irresponsible capitalists, the situation is getting worse, and the deterioration continues, and the danger is increasing gradually.

Organizations of protective human and animals care in addition to extinct protection and environment organization, try to do maximum effort to stop wrong behavior of capitalists nevertheless damage continue and dangerous increase more and more...

Whereas Islamic economy is more and values economy, the followers have convenience then use it and benefit from it in good way without any harm or pollution thus keep proceeding generation rights, benefit is yet the only goal but the goal is goal satisfaction and achieve success on earth.

According to Islamic Economics, moral values are given priority. So there is conviction and faith motivated to deal with the resources, leading to the use of resources in the best way, without causing damage or pollution, taking into account the moderation and the rights of future generations, but not profit alone as the goal. The main goal is not to achieve the maximum benefit possible, but the first goal above all is the satisfaction of God, and to fulfill the mission of succession on earth.

In addition to the above proposals, the following solutions can be made to solve the problems faced by the contemporary economic problems (Chapra.1996).

a- We must strengthen the human factor through increased education and training, and promoting moral and ethical values, leading to increased productivity of workers and thereby increase their incomes.

b- Rectify the effects of bias against rural development towards the cities and large industries, and the resulting decline in wages as a result of city congestion and thus reduce the overall demand and increased depression. 
c- Islam urges us to be fair and pay adequate wages, and can be accomplished by having the workers' share of the profits, or through the participation of the workers to own some shares in the companies they work for.

d- Must stop all measures and policies that enrich the minority at the expense of the majority.

e- Take steps reduce the centralization of power and bring reforms to land ownership and lease terms, and the development of rural infrastructure (irrigation, rural electrification, roads, markets).

f- Decrease in the number of large projects, except in certain cases where needed and promote small businesses, which reduces the concentration of wealth and increase social welfare, increase a sense of dignity ownership of businesses, to increase their enthusiasm for innovation, and a healthy environment for the best competition.

g- Influence in changing the tastes of consumers through moral values of faith and stop the lifestyle features that force them into illegal methods of satisfaction.

h- Must meet the basic necessities of the society, no matter how much developed is the country.

i- Cut government spending by closing the doors for corruption, waste and inefficiency.

j- There must be reforms to the financial institutions as the interest based system has failed to perform better and leads to injustice and inequality.

\section{Conclusion:}

The following important factors can be given as a conclusion from the above discussion:

1- Bringing reforms to the world with goodness and righteousness and the reduction of evil and corruption is the responsibility of all human.

2- Muslims present to humanity the favors that are not presented by any other nations from knowledge, science, manufacture, trade, inheritance, civilization. Many western scientists confess of these factors but, especially in the area of economics, Muslim Scholars played important additions in human thought.

3- Writings for Ibn Kaldun, Al Dalje and Al Ghazali and other Islamic scholars, distinguished and precedent in the area of economics, these literature and other Islamic science moved to Europe through the Crusades and the Andalusia and Sicily, and contributed largely to the Renaissance period.

4- Muslims have benefited greatly in the present era of modern science, especially in the field of economics. Muslim scholars were able to highlight and the formation of Islamic economics again. This resulted in many banks and financial institutions working according to Islamic system and proved success and superiority.

5- Islamic Economics does not keep silent over the intractable economic problems, but offers solutions and proposals, and invites to apply such principals. It is also a proven fact that the application of Islamic economics will lead to the disappearance of many economic problems. Researchers have provided a number of solutions to many economic problems such as inflation, unemployment, depletion of resources, recession and for the food shortage through Islamic Economics, especially the proposals by Dr. Omar Shaabra.

6- Knowledge and science is the right of everyone, and wisdom is the goal of the believer. Therefore, Islam does not prevent the use of western culture and even encourages further studies into whatever is useful and beneficial for the society. 
The Relationship Between Islamic Economics...

\section{المراجـع}

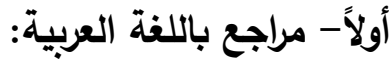

$$
\begin{aligned}
& \text { - - إبن خلدون، عبد الرحمن. (1984). المقدمـة. بيروت: دار الكلام. } \\
& \text { - العسال، أحمد. (1983). نظام الاقتصاد الإسلامي. القاهرة: دار غريب. } \\
& \text { - العقاد، عباس. (1977). الإسلام دعوة عالمية ـ بيروت: الدكتبة العصرية. } \\
& \text { - العوضي، رفعت. (1986). الاقتصاد الإسلامي. مكة المكرمة: دار الطالب الجامعي. } \\
& \text { - القرضاوي، يوسف. (1980). مشكلة الفقر وكيف عالجها الإسلام. القاهرة: مكتبة وهبة. } \\
& \text { - المودودي، أبو الأعلى. (1985). أساسيات الاقتصاد بين الإسلام والأنظمة المعاصرة. (د. ن). } \\
& \text { - - بابلي. محمود. (1995). الاقتصاد في ضوء الثربعة الإسلامية. بيروت: دار الكتاب اللبناني. } \\
& \text { - خضر، عبد العليم. (1985). أسس المفاهيم الاقتصادية في الإسلام. مكة المكرمة: رابطة العالم الإسلامي. } \\
& \text { - - زقزوق، محمود. (1994). الإسلام في مرآة الفكر الغربي. القاهرة: دار الفكر العببي. } \\
& \text { - شافعي، محمد زكي. (1982). مقدمة في النقود والبنوك. القاهرة: دار النهضة العربية. } \\
& \text { - شقير ، محمد. (1977). تاريخ الفكر الاقتصادي. القاهرة: دار نهضة مصر . } \\
& \text { - شمة، محمد. (1980). الإسلام في الفكر الأوروبي. القاهرة: مكتبة وهبة. } \\
& \text { - مشهور، نعمت. (1992). الاقتصاد الإسلامي والتضخم. المجلة العلمية لكلية التجارة. جامعه القاهرة. } \\
& \text { - - نامق، صلاح. (1980). اقتصاديات السكان في ظل التضخم السكانسي. القاهرة: دار الدعارف. } \\
& \text { - - يسري، عبد الرحمن. (1978). أسس التحليل الاقتصادي. الأسكندرية: مؤسسة شباب الجامعة. } \\
& \text { ثانيًا - مراجع باللغة الأجنبية: }
\end{aligned}
$$

- Chapra, Umar. (1996). Islam and the Economic Challenge. Washington: The International Institute of Islamic Thought. 